\section{An Inhibitory Growth Correlation in the Apothecial Stipe of Sclerotinia sclero- tiorum}

Although growth corrolations have been widely studied in the higher plants, thero havo been few observations of this phenomenon in the lower plants, and nono at all in the fungi. The occurrence of such at correlation in the apothecial stipe of the fungus Sclerotinia sclerotiorum (Lib.) D.By., $\mathbf{1 8 8 6}$, is described hore.

The S. sclerotiorum used was isolated from a discased bean pod of Phaseolus vulgaris from Spearwood, Westorn Australia, during September 1958.

Under certain conditions of moisturo and temperature, ono to several stipes, $0.5-0.8 \mathrm{~mm}$. in diamoter, may devolop on the surface of selerotia. No external supply of nutrionts is nocossary for this to occur. If the sclerotia and attached stipes are held in darkness, the stipes continue to grow in length without branching and may attrin longths up to $50 \mathrm{~mm}$. under laboratory conditions. If their apices are exposed to light each develops a single apothocium.

As extensive studies were being made on factors affocting the formation of apothocial stipes by sclerotia, germinating selorotia were roadily available. The sclerotia formed by each culture had boen airdried at $25^{\circ} \mathrm{C}$. for 3 weeks, sterilized in $1: 1,000$ mercuric chloride, washed in distilled water and placed in a Potri dish containing 1 per cent water agar. Tho dishes wore then placed in a dark ineubator at $15^{\circ} \mathrm{C}$. to induce the formation of apothecial stipes. 'This usually occurred within six weeks.

Twonty of the dishes were selectod at random. In each dish one selerotium with an apothecial stipe more than $10 \mathrm{~mm}$. in length was located. Tho apical regions of 1-2 mm. were removod with a razor from ten such stipes. The remaining ten stipes wero left intact as controls. The dishes were then partially sealed with 'Sellotape' to prevent desiccation and replaced in the incubator. Observations were mado weekly. The experiment was repeated using 20 apothocial stipes longer than $20 \mathrm{~mm}$., from half of which the apical $10 \mathrm{~mm}$. was removed.

Decapitatod stipes ceased to grow in length. Latoral branches, morphologically similar to the parent stipe, developed in 1-2 weeks at lower levols on all excopt two such stipes (Table 1). The withoring of the two stipes on which no branches formed probably resulted from damage to the point of attachment of tho stipo to the sclerotium during decapitation. Sometimes only one branch developed, but frequently several branches formed. Occasionally, soveral formod at one point on the stipo. In one or two instances, the apices of tho lateral branches rested in water on the surface of the agar. Such apices withered and branches formed on them at lower levols. No branchos developed on the intact stipos. Under suitablo light conditions all latoral branches, except the fow which had withered, formed apparently normal apothecia at their apices (Fig. 1).

Table 1. FonMation OF IATTRAT, BRANCHES ON DIOATITATED AND INTACT A POYH LOLAL STHLES

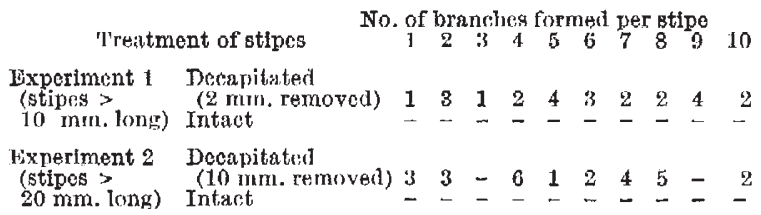

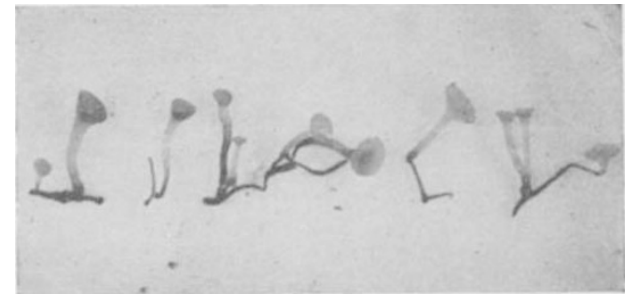

lig. 1. Mature apothecia at the apices of lateral branches on decapitated apothecial stipes. The silerotia have becn removed.

Tho origin of tho lateral branches of tho apothecial stipes of $S$. sclerotiorum is uncertain. They may originate from microscopic areas of meristematic tissuo normally provented from devoloping by the presence of the stipe apox. However, no such areas were observod in tho few longitudinal sections cxamined. It is doubtful, thorofore, if the phenomenon can be likened to that of apical dominance which occurs in higher plants. It is moro likoly that they arose as a result of inducod meristematic activity in mature cells following the removal of the stipe apex. In this event the phenomonon would be one of regeneration comparable, for example, with the development of adventitious shoots below the cut end of docapitated hypocotyls in eertain higher plants $^{2,7}$. Robertson ${ }^{8}$ suggested that branching of the hyphal apex of Fusarium oxysporurn following the arresting of the growth of the hyphal apex for more than $60 \mathrm{sec}$, might be explainod similarly.

Auxins are thought to be involved in corrolation phonomena in higher plants ${ }^{1,6,7}$. However, though auxins are known to be produced by many fungi, they have not boen assigned a growth-regulating rolo in those organisms'. 'This may bo because most experimental work has boen concerned with tho effect of auxins on growth of fungal mycelia rather than of fruit bodies. The inhibition of tho development of lateral branches by the intact apex of the apothecial stipe of $S$. sclerotiorum may be dotormined to somo extent by growth substances originating in the apex. Certainly the apothecial stipe of $S$. sclerotiorum appears to merit investigation as a source of growth-regulating substances in fungi.

\section{Rutr M. HENDERSON}

\section{C.S.I.R.O.,}

Division of Forest Products,

Yarra Bank Road, Melbourne.

${ }^{1}$ Audus, J. I., Plant Growth Substances (Leonari Mill Books, Ltd., London, 1050).

${ }^{2}$ Bain, H. F., Bot. Gaz., 101, 872 (1940).

${ }^{3}$ Gruen, H. E., Ann. Rev. Plant Physiol., 10, 405 (1959).

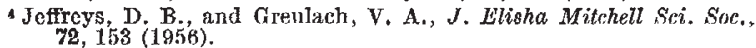

- Robertson, N. F., Ann. Bot., N.S., 22, 150 (1958).

- Sinnott, 1. W., Plant Morphogenesis (McGraw-Hill Book Co., Inc. $1060)$. "Wardlaw, C. W., Phylogeny and Morphogenesis (Macmillon and $\mathrm{C}$.,

\section{Germination of Resting Bodies in Verticillium Species}

Although detailed investigations have been carried out on the morphology, physiology and pathology of Verticillium spocios, there are very fow references to tho function and germination of the 